\title{
Unemployment and Debt Dynamics in a Highly Indebted Small Open Economy
}

\author{
By Burkhard Heer ${ }^{a, b,}{ }^{\dagger}$ and Stefan Franz Schubert ${ }^{a}$ \\ ${ }^{a}$ Free University of Bozen-Bolzano, School of Economics and Management, Piazza Università 1, \\ 39100 Bolzano-Bozen, Italy, Burkhard.Heer@unibz.it; SSchubert@unibz.it \\ ${ }^{b}$ CESifo
}

published as: Heer, B. and S.F. Schubert, 2012, Unemployment and debt dynamics in a highly indebted small open economy, Journal of International Money and Finance, vol. 31, 1392-1413.

JEL classification: F34, F41, J64

Keywords: Unemployment, debt, interest rate premium, haircut, sticky wages

\begin{abstract}
The paper analyzes the dynamic effects of a total factor productivity shock and an interest rate risk premium shock in a highly indebted open economy. In contrast to the standard open economy framework, search unemployment and wage bargaining are introduced. We find that a negative total factor productivity shock primarily has effects on the economy's production side and on welfare, but not on its stock of foreign debt and the country specific risk premium, and large part of the adjustment happens in the short run. In contrast, a pure increase in the country specific risk premium causes substantial dynamics and a considerable reduction in foreign debt, allowing higher consumption in the long run and creating an intertemporal welfare gain, even though unemployment increases strongly in the short run. A $50 \%$ haircut of foreign debt significantly reduces the initial response of the unemployment rate. In case of a temporary productivity shock, sticky wages imply smaller employment, but generate higher welfare than flexible wages.
\end{abstract}

${ }^{\dagger}$ Corresponding author: Tel.: +390471013200, Fax: +390471013009. 


\section{Introduction}

The 2007 - 2009 global financial crisis has provoked a severe contraction of economic activity as credit supply fell ("credit crunch") and international trade declined. Peaking in September 2008, the ability of the financial system to allocate loanable funds has been persistently constrained and total factor productivity (TFP) has fallen (see IMF (2009, ch. 4)). Several recent studies provide support for this view (see, e.g., Estevão and Severo (2010), Haugh, Ollivaud, and Turner (2009), Meza and Quintin (2005), and Cole, Ohanian, and Leung (2005)). ${ }^{1}$

On the international financial market, countries which already had a high foreign debt to GDP ratio and disadvantageous macroeconomic prospects in terms of growth, unemployment, or structural labor market weaknesses, where charged with high risk premia. E. g., the interest rate spread between Greece and Germany was raised from close to zero in 2006 to roughly 4 percentage points in January 2010. Many of these highly-indebted countries also suffer from persistent and higher unemployment. In the troubled countries of the Euro-zone - Portugal, Ireland, Greece, and Spain - the harmonized OECD unemployment rates increased from $8.1 \%$ to $11.1 \%, 4.6 \%$ to $13.7 \%$, $8.3 \%$ to $12.9 \%$, and $8.3 \%$ to $20.5 \%$ between 2007 and the third quarter of 2010 , respectively. In consideration of these observations, the focus of this paper is the explanation of the unemployment dynamics in highly-indebted open economies in the aftermath of negative TFP shocks and increases in the interest rate risk premium.

In order to understand the behavior of unemployment in these countries, we need to study the flows in and out of employment. In this vain, Rogerson and Shimer (2010) decompose the fluctuations in total hours worked into changes in employment and changes in hours worked per worker for a large set of OECD countries. They find that "movements in and out of the labor force are relatively unimportant at business cycle frequencies in the United States." While the empirical evidence for European countries is mixed, these authors show that this effect is even less relevant for Ireland and, in particular, the Southern European countries like Greece, Spain, and Portugal that we have in mind for this study (compare Figure 3 in Rogerson and Shimer (2010)). From this observation, they conclude that "changes in unemployment over the business cycle capture a great deal of the change in total hours worked over the business cycle, and so to a first approximation, understanding cyclical fluctuations in total hours amounts to understanding the movement of workers between employment and unemployment." We consider the search model of Pissarides (2000) as a convenient framework to analyze these flows.

In order to analyze the dynamics of unemployment, we therefore augment and modify the standard representative agent model of a one-sector, two-good open economy (see, e.g., Turnovsky (2000,

\footnotetext{
${ }^{1}$ As one of the few exceptions, Petrosky-Nadeau (2010) comes to the opposite conclusion that TFP increased after the 2008 financial crisis.
} 
ch. 11)) by introducing search unemployment a la Mortensen and Pissarides ${ }^{2}$ and wage bargaining in a similar way as in the closed economy models of Shi and Wen (1997, 1999) and Heer (2003). Unemployment results from time-consuming and costly matching of vacancies with agents who search for a job. In addition, we also discuss the effects of sticky wages on unemployment dynamics and welfare.

Our model follows Schubert (2011) and differs from Shi (2001) and the closed economy versions of Shi and Wen $(1997,1999)$ and Heer (2003) in several important aspects. First, the representative agent's utility function is assumed to be non-separable with respect to consumption and leisure, allowing for richer consumption dynamics. Second, we introduce investment adjustment costs, giving rise to a Tobin $q$ theory of investment. This enriches the dynamics and allows us to investigate the time profile of stock prices (the price of capital). Third, we depart from the assumption that the production function is Cobb-Douglas and use the more general constant elasticity of substitution (CES) specification. Fourth, we endogenize the interest rate by imposing a country specific risk premium which depends on the country's ability to service its foreign debt, proxied by the debt-GDP ratio. Fifth, we introduce sticky wages into the model.

We find that a pure total factor productivity shock has a modest short-run effect on unemployment and leads to a decumulation of capital and debt. The debt dynamics, albeit small in magnitude, induce a capital flow reversal. The welfare loss of the shock is considerable. In contrast, a pure interest risk premium shock leads to a large increase in unemployment. The capital stock, output, and labor evolve in a non-monotonic way, and during transition the economy drastically reduces its debt. The overall welfare effect of an increase in the risk premium is positive. This implies that from a long-run point of view, the increase in a country's risk premium is welfare improving. If the two shocks occur together, the responses of capital, output, unemployment, and the interest rate reinforce themselves, whereas the consumption adjustment is dampened, and the welfare loss is reduced. If the shock is combined with a $50 \%$ debt cancelation, the welfare loss is less than half as large because of the lower debt service. In case of a transitory TFP shock combined with a risk premium shock, there is a welfare gain. If, in addition, real wages are sticky, unemployment is much more persistent.

The paper is structured as follows. The model is introduced in Section 2 and calibrated in Section 3. The steady-state effects of the shocks are presented in Section 4. We separately study the dynamic effects of (i) a negative total factor productivity (TFP) shock and (ii) an exogenous increase in the country's interest rate risk premium in Sections 5 and 6, respectively. In Section 7, we consider a combination of both shocks and study how economic activity is reduced. Section 8 presents our results for a $50 \%$ haircut of foreign debt. Finally, we analyze the effects of a transitory TFP shock

\footnotetext{
${ }^{2}$ See Pissarides (2000) for an overview.
} 
in presence of labor market frictions in the form of sticky wages in Section 9. Section 10 concludes. $^{3}$

\section{The Model}

The model introduces search into a semi-small open economy model of the Turnovsky (2000, ch. 11.3, 11.4) type. Four sectors can be distinguished: households, firms, the government, and the international sector, which we consider in turn.

\subsection{Households}

The domestic economy is populated by many identical households. Each household consists of a continuum of agents with a fixed measure. Each household is endowed with one unit of time, which can be used for labor (supply) $l^{s}$, search, $s$, or leisure, $L=1-l^{s}-s$. Agents who are searching are called unemployed agents. Thus, $l^{s}$ can be interpreted as time used for working (employment), $s$ as the time used for searching (unemployment), and $L$ as time enjoying leisure. The labor force is defined as $l^{s}+s$, and the unemployment rate as $s /\left(l^{s}+s\right)$. Besides leisure, each household consumes a consumption bundle $c$, containing the domestically produced good, $c_{d}$, and the imported consumption good, $c_{f}$, which are combined according to the linearly homogenous aggregator (sub-utility) function

$$
c=\left(\kappa^{\frac{1}{\psi}} c_{d}^{\frac{\psi-1}{\psi}}+(1-\kappa)^{\frac{1}{\psi}} c_{f}^{\frac{\psi-1}{\psi}}\right)^{\frac{\psi}{\psi-1}}
$$

where $\kappa$ is the weight of the domestically produced good $(0<\kappa<1)$, and $\psi$ denotes the intratemporal elasticity of substitution between the domestic and the foreign consumption good.

The economy has access to a world capital market, allowing it to borrow internationally. However, it faces restrictions in doing so, according to lenders' assessment of its creditworthiness. We incorporate this by assuming that the international capital market imposes a borrowing premium (risk premium), which is an increasing function $\omega$ of the ratio of the country's stock of foreign debt, $n$, to the value of its GDP, $y / p$, expressed in terms of the foreign good (to be determined in equilibrium), i.e.

$$
r=r^{*}+\omega\left(\frac{p n}{y}\right), \quad \omega^{\prime}(.)>0
$$

where $r^{*}$ is the exogenously given riskless world interest rate (e. g. the LIBOR). Equation (1b) represents an upward sloping supply curve of foreign debt. In making his borrowing/lending decisions, the agent takes the interest rate as given. This is because the interest rate facing the nation is a

\footnotetext{
${ }^{3}$ Computational details are presented in an Appendix that is available from the authors upon request.
} 
function of its aggregate debt, which the representative agent, being atomistic, rationally assumes that he cannot influence.

The representative household ${ }^{4}$ earns wage income from labor and gets the after-tax profits $\pi$ of the representative firm he owns, and uses his income to pay interest on his debt $b$ (denoted in terms of the foreign good), to purchase the consumption bundle $c$, the price of which is $P$, and to pay lump-sum taxes, $T$. His flow budget constraint is thus

$$
\dot{b}=\frac{1}{p}\left[p r b+P c+T-\pi-\left(1-\tau_{w}\right) w l^{s}\right]
$$

where $p$ denotes the real exchange rate (the relative price of the imported good in terms of the domestic good).

The variable $w$ denotes the wage rate, and $\tau_{w}$ the labor income tax rate. The variable $P$ denotes the price of the consumption bundle in terms of the domestic good and is defined as

$$
P \equiv\left(1+\tau_{c}\right)\left(\kappa+(1-\kappa) p^{1-\psi}\right)^{\frac{1}{1-\psi}}
$$

where $\tau_{c}$ is the consumption tax rate. ${ }^{5}$

A distinguishing feature of the model is that labor (employment) $l$ changes only gradually according to

$$
i^{s}=\phi s-\zeta l^{s}
$$

where $\phi$ denotes the job finding rate, which the individual agent takes as given, and $\zeta$ is the exogenously given rate of job separation. ${ }^{6}$

The representative household derives utility from consumption $c$ and leisure $L$. He maximizes the intertemporal iso-elastic utility function $W$

$$
W \equiv \int_{0}^{\infty} \frac{1}{\epsilon}\left[c(1-l-s)^{\theta}\right]^{\epsilon} e^{-\beta t} d t, \quad-\infty<\epsilon<1, \quad \theta \geq 0, \quad 1>\theta \epsilon, \quad 1>\epsilon(1+\theta)
$$

by choosing the rates of consumption, $c$, and search, $s$, and the rates of bonds and labor accumulation, subject to the flow budget constraints (1c) and (1e), and the given initial stocks of traded

\footnotetext{
${ }^{4}$ For the sake of simplicity, in what follows we suppress the subscript $i$, indicating agent $i$.

${ }^{5}$ The expression for $P$ is derived by solving the expenditure minimization problem $\min _{c_{d}, c_{f}}\left(1+\tau_{c}\right) c_{d}+\left(1+\tau_{c}\right) p c_{f}$ s.t. $c=1$, where $c$ is defined in (1a). That is, $P$ denotes the minimum expenditure in terms of the domestic good necessary to buy one unit of $c$. The rates of consumption follow then as $c_{d}=\kappa\left(\left(1+\tau_{c}\right) / P\right)^{-\psi} c$ and $c_{f}=(1-\kappa)\left(\left(1+\tau_{c}\right) p / P\right)^{-\psi} c$. See Obstfeld and Rogoff (1996), pp. 226.

${ }^{6}$ Following Shi and Wen $(1997,1999)$, and Heer (2003), the job destruction rate is assumed to be exogenous to not further complicate the model. Moreover, as it is discussed in Pissarides (2000, ch. 2), the dynamics in case of an endogenous job destruction rate are similar to those derived in a model where the job separation rate is exogenous.
} 
bonds, $b(0)=b_{0}$, and labor, $l^{s}(0)=l_{0}^{s}$, respectively. $\beta$ denotes the agent's rate of time preference, taken to be constant. The intertemporal elasticity of substitution w. r. t. the consumption bundle $c$ is equal to $1 /(1-\epsilon)$, and $\theta$ denotes the elasticity of leisure. The household's first order conditions are given by

$$
\begin{aligned}
& c^{\epsilon-1}\left(1-l^{s}-s\right)^{\epsilon \theta}=\lambda \frac{P}{p} \\
& \theta c^{\epsilon}\left(1-l^{s}-s\right)^{\epsilon \theta-1}=\nu \phi \\
& \beta-\frac{\dot{\lambda}}{\lambda}=r \\
& \frac{\lambda\left(1-\tau_{w}\right) w}{\nu p}+\frac{\dot{\nu}}{\nu}-\zeta=\beta+\phi
\end{aligned}
$$

and the transversality conditions

$$
\lim _{t \rightarrow \infty} \lambda b e^{-\beta t}=\lim _{t \rightarrow \infty} \nu l^{s} e^{-\beta t}=0
$$

where $\lambda$ is the shadow value of wealth in the form of internationally traded bonds, i. e., the marginal utility of wealth, and $\nu$ is the shadow price of employment. Condition (3a) equates the marginal utility of consumption of the consumption bundle to the marginal utility of wealth, measured in terms of the consumption bundle. Equation (3b) equates the marginal cost of search (i.e. the (dis)utility) to the marginal benefit of search, i. e. the probability of finding a job times the value of employment. The dynamic equation (3c) requires the rate of return on consumption to be equal to the rate of return on bonds. The dynamic no-arbitrage condition (3d) requires the rate of return on employment, comprising the "dividend yield" of employment, $\lambda\left(1-\tau_{w}\right) w /(\nu p)$, the "capital gain" $\dot{\nu} / \nu$ and the loss due to job destruction $\zeta$, to be equal to the "effective" discount rate $\beta+\phi$. Finally, in order to ensure that the agent's intertemporal budget constraint is met, the transversality conditions (3e) must hold.

\section{$2.2 \quad$ Firms}

The economy comprises also a large number of identical firms. Firms produce a domestic good, $y$, by combining capital, $k$, and labor, which is demanded at an amount $l^{d}$, by means of a constant elasticity of substitution (CES) production function

$$
y=A\left[\alpha k^{-\rho}+(1-\alpha)\left(l^{d}\right)^{-\rho}\right]^{-\frac{1}{\rho}}, \quad-1 \leq \rho<\infty, 0<\alpha<1
$$

where $A$ is a scale parameter, summarizing total factor productivity, and $\alpha$ denotes the share of capital in production. The constant elasticity of substitution is given by $\sigma \equiv 1 /(1+\rho)$. Capital accumulation is due to convex installation costs, resulting in a total investment cost function

$$
\Phi(I, k)=I+h \frac{I^{2}}{2 k}=I\left(1+\frac{h}{2} \frac{I}{k}\right)
$$


where adjustment costs are convex in $I$ and proportional to the rate of investment per unit of installed capital, $I / k$. Letting $\delta$ denote the rate of depreciation of the capital stock, the rate of capital accumulation is given by

$$
\dot{k}=I-\delta k
$$

Workers separate from a job at rate $\zeta$. The individual firm takes the probability $\varphi$ of filling a vacancy $v$ as given. Hence, the firm's employment follows

$$
i^{d}=\varphi v-\zeta l^{d}
$$

The firm has to pay a cost for maintaining a number of job vacancies equal to $m v$. This cost includes advertising costs (Pissarides (1987)), and can also be thought of as a hiring/recruiting cost (Pissarides (1986), Mortensen and Pissarides (1994)), and/or as the cost of a human resources division. The firm's operating profit (capital earnings), $y-w l^{d}-m v$, is taxed at rate $\tau_{k}$. Thus, the firm's net profits are given by

$$
\pi=\left(1-\tau_{k}\right)\left(y-w l^{d}-m v\right)-\Phi(I, k)
$$

The firm's objective is to maximize the value of the firm, i. e. the present value of profits, $V$

$$
V \equiv \int_{0}^{\infty} \pi(t) e^{-\int_{0}^{t} r_{d}(z) d z} d t
$$

by choosing investment $I$, vacancies $v$, the rates of capital accumulation and labor $l^{d}$, subject to equations (4c) and (4d), and the initial stocks of capital and labor, $k(0)=k_{0}$ and $l^{d}(0)=l_{0}^{d} \cdot r_{d}$ denotes the domestic interest rate. In equilibrium, uncovered interest rate parity holds, and the domestic interest rate is equal to the foreign interest rate plus the rate of depreciation of the real exchange rate,

$$
r_{d}=r+\frac{\dot{p}}{p}
$$

Solving the firm's optimization problem gives rise to the following first order conditions:

$$
\begin{aligned}
& 1+h \frac{I}{k}=q \\
& \left(1-\tau_{k}\right) m=\xi \varphi \\
& \frac{\left(1-\tau_{k}\right) \alpha A^{-\rho}\left(\frac{y}{k}\right)^{1+\rho}}{q}+\frac{\dot{q}}{q}+\frac{(q-1)^{2}}{2 q h}-\delta=r+\frac{\dot{p}}{p} \\
& \frac{\left(1-\tau_{k}\right)(1-\alpha) A^{-\rho}\left(\frac{y}{l^{d}}\right)^{1+\rho}}{\xi}+\frac{\dot{\xi}}{\xi}-\frac{\left(1-\tau_{k}\right) w}{\xi}-\zeta=r+\frac{\dot{p}}{p} \\
& \lim _{t \rightarrow \infty} q k e^{\int_{0}^{t}-(r+\dot{p} / p) d \tau}=\lim _{t \rightarrow \infty} \xi l^{d} e^{\int_{0}^{t}-(r+\dot{p} / p) d \tau}=0
\end{aligned}
$$


where $q$ is the market price of installed capital and $\xi$ denotes the shadow price of labor. Equation (6a) determines the rate of investment, $I$, and gives rise to a Tobin $q$ theory. Given the capital stock, the higher $q$, the more the firm will invest. Equation (6b) equates the marginal cost of vacancy to its marginal benefit. The dynamic no-arbitrage relation (6c) requires that the rate of return on capital is equal to the domestic interest rate. The rate of return on domestic capital comprises four terms. The first is the "dividend yield", the second the capital gain, the third reflects the fact that a benefit of a higher capital stock is to reduce the installation costs (which depend on $I / k$ ) associated with new investment, whereas the fourth element represents a loss due to the depreciating capital stock. The no-arbitrage relation (6d) equates the rate of return on labor, comprising a "dividend yield", a "capital gain", and two losses due to wage payments and job destruction, to the domestic interest rate. Finally, the transversality conditions (6e) must hold.

\subsection{Goods Market Clearing}

Domestic goods market equilibrium requires that output is allocated to domestic consumption, government spending, $g$, investment expenditures, exports, and hiring costs, i. e.

$$
y=c_{d}+g+\Phi(I, k)+Z(p)+m v
$$

where $Z(p)$ denotes exports as a function of the real exchange rate. We shall assume that export demand is a function with constant price elasticity $\varepsilon$

$$
Z(p)=Z_{0} p^{\varepsilon}
$$

where $Z_{0}$ represents an exogenous shift parameter. Goods market clearance (7) is maintained by proper adjustments of the real exchange rate, $p$.

\subsection{Matching and Wage Determination}

As in Shi and Wen (1997, 1999), and Heer (2003), labor markets are subject to frictions and are characterized by two-sided search. Matching vacancies with searching agents is a time-consuming process. To simplify notation, $v$ and $s$ also denote the aggregate numbers of vacancies and searching agents, respectively. We assume a constant returns to scale matching technology of the CobbDouglas form

$$
M(v, s)=B v^{\chi} s^{1-\chi}, \quad B>0,0<\chi<1
$$

Thus, matches per unemployed agent can be expressed as $\phi=B(v / s)^{\chi}$, and matches per vacancy as $\varphi=B(v / s)^{\chi-1}$. Hence, the probabilities of finding a job and of filling a vacancy are endogenously 
determined, whereas households and firms take them as given. Defining $x \equiv v / s$ as the vacancyunemployment ratio, we can write

$$
\phi(x)=B x^{\chi}, \quad \varphi(x)=B x^{\chi-1}
$$

where we see that matches per searching agent $\phi$ are an increasing function in the vacancyunemployment ratio, whereas matches per vacancy $\varphi$ are a decreasing function in $x$.

Once an unemployed agent is matched with a vacancy, the agent and the firm negotiate the time path of the agent's wage rate $w$. Wages are measured in terms of the domestic good and are determined by Nash bargaining. Hiring an additional worker will increase the firm's surplus by $(\partial y / \partial l-w)$. By accepting a job offer, the household's income rises by $\left(1-\tau_{w}\right) w$, the value of which in terms of utility is $(\bar{\lambda} / p)\left(1-\tau_{w}\right) w$. On the other hand, an increase in labor reduces agent's utility by $\theta c^{\epsilon}\left(1-l^{s}-s\right)^{\theta \epsilon-1}$. Noting that from (3a) $\bar{\lambda} / p=c^{\epsilon-1}\left(1-l^{s}-s\right)^{\theta \epsilon}$, we can express the worker's net

gain in terms of the domestic good as $w-\frac{\theta P c}{\left(1-l^{s}-s\right)\left(1-\tau_{w}\right)}$, where the second term can be interpreted as the household's reservation wage. Hence, the Nash bargaining solution solves

$$
\max _{w}\left((1-\alpha) A^{-\rho}\left(\frac{y}{l^{d}}\right)^{1+\rho}-w\right)^{1-\varrho}\left(w-\frac{\theta P c}{\left(1-l^{s}-s\right)\left(1-\tau_{w}\right)}\right)^{\varrho}
$$

The parameter $0<\varrho<1$ measures the bargaining power of workers. The solution of the Nash bargaining game gives the wage rate

$$
w=\varrho(1-\alpha) A^{-\rho}\left(\frac{y}{l^{d}}\right)^{1+\rho}+(1-\varrho) \frac{\theta P c}{\left(1-l^{s}-s\right)\left(1-\tau_{w}\right)}
$$

Thus, the wage rate is a weighted average of the marginal product of labor and the agent's reservation wage. Accordingly, the wage lies between the marginal product of labor and the marginal rate of substitution of leisure for consumption. This in sharp contrast to the standard model with a neoclassical labor market, where the wage rate equals both the marginal product of labor and the marginal rate of substitution. Note that, ceteris paribus, the wage rate depends positively on the price for the consumption bundle, $P$, which in turn is an increasing function of the real exchange rate, $p($ see $(1 \mathrm{~d}))$.

\subsection{Macroeconomic Equilibrium}

The macroeconomic equilibrium is defined as follows (see Shi and Wen (1997, 1999), Heer (2003)).

Definition. The competitive search equilibrium is a collection of decision rules $\{c, s, b, l, I, v, k\}$ and prices $\{q, w, p\}$ such that

1. Individual variables equal (average) aggregate variables. 
2. Households maximize their utility (2) subject to (1).

3. Firms maximize the value of the firm (5) subject to (4).

4. Wages are given by (10).

5. The market price of capital evolves according to (6c).

6. The real exchange rate $p$ adjusts properly to continuously clear the domestic goods market (7).

7. Capital and aggregate debt accumulate according to (4c) and (12b), respectively.

8. Agents do not take into account the effect of their decisions on the matching rates $\phi$ and $\varphi$. In equilibrium, $\varphi v=\phi s$.

9. Employment evolves according to (1e).

10. Agents do not take into account the effect of their decisions on the interest rate $r$ which is given by $(1 b)$.

Since the flow of workers in and out of employment are equal to each other in an symmetric equilibrium, that is $\varphi(x) v=\phi(x) s$, equations (1e) and (4d) tell us that the supply of labor equals the demand for labor, i. e. $l^{s}=l^{d}=l$. Note that this market clearing condition does not pin down the wage rate $w$ as in the neoclassical framework. Rather, the wage rate is a result of bargaining and follows from equation $(10) .^{7}$

\subsection{Current Account}

The stock of aggregate foreign debt in the economy is defined as the sum of private debt $b$ and public debt $a$, i. e., $n \equiv b+a$, Adding the government's flow budget constraint

$$
\dot{a}=\frac{1}{p}\left[g+p r a-\tau_{k}(y-w l-m v)-\tau_{w} w l-\tau_{c}\left(c_{d}+p c_{f}\right)-T\right]
$$

to (1c) yields the national budget constraint

$$
\dot{n}=\frac{1}{p}\left[p r n+c_{d}+p c_{f}+g+\Phi(I, k)+m v-y\right]
$$

i. e. the negative of the economy's current account. Equation (12) states that the economy accumulates foreign debt to finance its expenditures on consumption, investment, vacancy costs, and

\footnotetext{
${ }^{7}$ On this issue, see Shi and Wen (1999, p. 465).
} 
interest payments net of output produced. Inserting (7) into (12a), national foreign debt accumulation $\dot{n}$ (the negative of the country's current account) can equivalently be written as

$$
\dot{n}=r n-\left(\frac{Z(p)}{p}-c_{f}\right)
$$

where $Z(p) / p-c_{f}$ is the trade balance, expressed in terms of the foreign good. Combining the transversality conditions for households and the government ${ }^{8}$ gives rise to the intertemporal budget constraint

$$
\lim _{t \rightarrow \infty} n e^{-\int_{0}^{t} r(\tau) d \tau}=0
$$

The steady state and the dynamics of the economy are described in more detail in the Appendix that is available from the authors upon request.

\section{Calibration Strategy}

The period length is equal to one year. Our functional form for the country specific borrowing premium (13) follows Lim and McNelis (2008, ch. 2) and Eicher, Schubert, and Turnovsky (2008):

$$
\omega\left(\frac{p n}{y}\right)=e^{\eta \frac{p n}{y}}-1
$$

In our model, we have to calibrate the preference parameters $\{\beta, \epsilon, \psi, \kappa\}$, the production parameters $\{A, \rho, \alpha, \delta, h\}$, the policy instruments $\left\{\tau_{k}, \tau_{w}, \tau_{c}, g\right\}$, the parameters of the export function $\left\{Z_{0}, \varepsilon\right\}$, the labor market parameters $\{\chi, \zeta, \varrho, B, \gamma, m\}$, the exogenous world interest rate, $r^{*}$, and the parameter of the interest rate premium rule, $\eta$. A summary of the calibration is provided in Table 1.

We choose standard parameters for our calibration. The value for the time preference rate $\beta=0.04$ is chosen so that the domestic real interest rate amounts to $4 \%$ in steady state. The preference parameter $\epsilon$ is set equal to -1.5 and corresponds to an intertemporal elasticity of substitution of 0.4. Following Backus, Kehoe, and Kydland (1994), the consumption aggregator function (1a) is assumed to have an intratemporal elasticity of substitution between the domestic and foreign good of $\psi=1.5$, implying that domestic and foreign goods are substitutes in consumption. The parameter $\kappa$, measuring the weight of the domestic good in the consumption basket, is assumed to take the value 0.5 , corresponding with an initial import-output ratio of roughly 0.31 , which is close to the values for, e.g., Greece, Portugal, and Spain. The elasticity of leisure, $\theta$, is the key determinant of the equilibrium labor-leisure allocation and has been set to 1.0 so that the equilibrium fraction

\footnotetext{
${ }^{8}$ For the government to remain solvent, we require $\lim _{t \rightarrow \infty} a e^{-r t}=0$.
} 
of time devoted to leisure $(1-l-s)$ amounts to approximately 0.7 , consistent with empirical observations.

As recent empirical evidence (see, e.g., Papageorgiou (2008)) suggests that the elasticity of substitution in production, $\sigma$, is well below unity, we pick $\rho=1 / 3$ as our benchmark, implying a production elasticity of substitution equal to $\sigma=0.75$. The share of capital in production is set equal to $\alpha=1 / 3$ and is standard. The rate of depreciation equals 0.05 , a value that is usually assumed, see, e.g., Chatterjee and Turnovsky (2007). The initial productivity parameter $A$ is set equal to unity. The choice of adjustment costs is less obvious and $h=12$ lies within the range of 10 to 16 generally assumed in the literature. ${ }^{9}$

The level of government spending $g$ is chosen in a way to obtain an empirically plausible ratio of government spending to GDP of about 0.2. The tax rates on gross operating profits (capital income), labor, and consumption are chosen in accordance with recent empirical evidence and earlier search models. ${ }^{10}$

The initial real exchange rate is normalized to unity $\left(p_{0}=1\right)$, and the export shift parameter $Z_{0}$ is adjusted in a way to maintain domestic goods market equilibrium. As in Schubert (2011), the elasticity of exports with respect to the real exchange rate, $\varepsilon$, is set equal to $4 .^{11}$

$\zeta$ is set equal to an annual job separation rate of $12.5 \%$ which is in accordance with recent findings of Hobijn and Şahin (2009). ${ }^{12}$ The bargaining power of workers and firms is assumed to be equal, therefore we choose $\varrho=0.5 .^{13}$ The values of $\chi$ and $B$ are taken from Shi and Wen (1999) and Heer (2003).

\footnotetext{
${ }^{9}$ Ortigueira and Santos (1997) show that the speed of convergence is sensitive to $h$, and choose $h=16$ on the grounds that it generates a speed of convergence of around 2 percent per annum, consistent with much empirical evidence. Auerbach and Kotlikoff (1987) assume $h=10$, and recognize that this is at the low value of estimates, while Barro and Sala-i-Martin (2003) propose a somewhat larger value.

${ }^{10}$ Shi and Wen (1999) choose $\tau_{k}=\tau_{w}=0.3$ in their simulations. Elschner and Vanborren (2009) calculate an effective average corporate tax rate of $22.3 \%$ for the EU27 and of $26.3 \%$ for the EU15, but detect considerable dispersion (e.g., the lowest value was found in Bulgaria (8.8\%), and the highest in Germany (35.5\%)). Carey and Tchilinguirian (2000) calculated average effective tax rates in OECD countries. The tax rate on gross operating surplus for the OECD average was $26.6 \%$, while for the G7 it was $30.7 \%$. For labor, the tax rates where $33.4 \%$ and $29.8 \%$, respectively. The tax rate on consumption was $17.1 \%$ for the OECD average and $18.7 \%$ for the EU average.

${ }^{11}$ We are aware that estimates of export elasticity w.r.t. the real exchange rate (RER) are much lower. They range between close to zero and 1.6, see, e.g., Colacelli (2008), Hooper, Johnson, and Marquez (2000), Bayoumi (1999), and others. The reason for choosing a value of $\varepsilon=4$ rather than, say, unity is that the model should give rise to reasonable exchange rate movements, keeping in mind that the model does not allow for price rigidities, and that the RER has to adjust to clear the goods market.

${ }^{12}$ In contrast to Hobijn and Şahin (2009), who estimated monthly job separation rates for 23 OECD countries, $\zeta$ is expressed on an annual basis.

${ }^{13}$ Shi and Wen (1999) and Heer (2003) calibrate their models with a slightly different value (0.4).
} 
The riskless world interest rate is set to $r^{*}=3 \%$.

Table 1: Baseline calibration

\begin{tabular}{lccccc}
\hline \hline Preferences & $\beta=0.04$ & $\epsilon=-1.50$ & $\psi=1.50$ & $\kappa=0.5$ & $\theta=1.0$ \\
Production & $A=1.00$ & $\rho=1 / 3$ & $\alpha=1 / 3$ & $\delta=0.05$ & $h=12$ \\
Government & $\tau_{k}=0.3$ & $\tau_{w}=0.3$ & $\tau_{c}=0.2$ & $g=0.08$ & \\
Exports & $Z_{0}=0.146$ & $\varepsilon=4.0$ & & & \\
Labor market & $\chi=0.6$ & $\zeta=0.125$ & $\varrho=0.50$ & $B=1.0$ & $m=0.4$ \\
Interest rate rule & $r^{*}=0.03$ & $\eta=0.01$ & & & \\
\hline
\end{tabular}

A crucial parameter for the dynamics of indebted countries in response to a change in output is the interest-rate rule parameter $\eta$, which summarizes the sensitivity of the risk premium to the country's stock of aggregate debt, and thus characterizes its degree of access to the world financial market. Empirical evidence on this is somewhat mixed though most studies, and particularly the more recent ones, obtain a significant and convex relationship. ${ }^{14}$ Since these empirical studies embed this effect in larger structural empirical relationships, it is hard to relate the impact of the debt-output ratio to the value of $\eta \cdot{ }^{15}$ The value of $\eta$ is the crucial determinant of the equilibrium debt-output ratio. A value of $\eta=0.01$ proxies unlimited access to the international financial market, which was the case for the countries we consider before the world financial crisis occurred. Further support for our benchmark value $\eta=0.01$ is that it yields a plausible equilibrium debt-output ratio of around $100 \%$, which is characteristic for some highly indebted economies like Greece, Irland and Portugal.

Our calibration of the labor market parameters implies an equilibrium unemployment rate of $8.17 \%$. The steady-state values of our model, using the benchmark calibration, are presented in Table 2, reflecting a highly indebted economy with a debt-output ratio of approximately unity. The critical equilibrium ratios are all in their respective ranges. ${ }^{16}$

\footnotetext{
${ }^{14}$ See e. g. Edwards (1984), Min (1998), Zoli (2004), and Chung and Turnovsky (2010), among others, who obtain significant positive effects for the effect of debt on the borrowing premium. Zoli (2004) emphasizes the nonlinear increasing (convex) feature of this relationship, an aspect that is incorporated in the exponential formulation we employ.

${ }^{15}$ For example, Chung and Turnovsky (2010) find that both the debt-GDP ratio and its interaction with risk measures (output volatility and real exchange rate volatility) are significant determinants of the borrowing premium.

${ }^{16}$ The capital value-output ratio $q k / y$ is 2.5 , the consumption-output ratio $P c / y$ is 0.62 , the share of labor income in GDP is 0.65 , the debt-GDP ratio $p n / y$ is 0.995 , and labor is roughly one third (0.343) of available time.
} 
Table 2: Benchmark steady-state values $(A=1.0, \eta=0.01)$

\begin{tabular}{|l|l|l|l|l|l|l|l|l|l|}
\hline \hline$\tilde{k}$ & $\tilde{n}$ & $\tilde{l}$ & $\tilde{s}$ & $\tilde{p}$ & $\tilde{p} \tilde{n} / \tilde{y}$ & $\tilde{w}$ & $\tilde{c}$ & $\tilde{y}$ & $\widetilde{U E}$ \\
\hline 0.652 & 0.416 & 0.343 & 0.0305 & 1.000 & 0.995 & 0.787 & 0.258 & 0.418 & 8.17 \\
\hline
\end{tabular}

Notes: A tilde denotes steady-state. $U E$ denotes the unemployment rate $U E \equiv s /(l+s)$.

\section{Steady State Effects}

The steady-state effects of a fall of the productivity $A$ from 1.0 to 0.97 and/or an increase of the interest rate parameter $\eta$ from 0.01 to 0.03 are expressed in percentage changes and are summarized in Table 3. The table also contains the short-run and long-run unemployment rates $U E(0)$ and $\widetilde{U E}$ and the welfare changes $\Delta W(0) \%$ and $\Delta \tilde{W} \%$, respectively. ${ }^{17}$

Table 3: Effects of shocks

\begin{tabular}{l|c|c|c}
\hline \hline & $A=0.97$ & $A=1.0$ & $A=0.97$ \\
& $\eta=0.01$ & $\eta=0.03$ & $\eta=0.03$ \\
\hline$\Delta \tilde{y} \%$ & -3.59 & -2.15 & -5.74 \\
$\Delta \tilde{k} \%$ & -2.76 & -2.15 & -5.06 \\
$\Delta \tilde{n} \%$ & -2.4 & -66.8 & -67.8 \\
$\Delta \tilde{p} \%$ & -0.2 & -1.6 & -2.8 \\
$\Delta \tilde{l} \%$ & 0 & -2.33 & -2.04 \\
$\Delta \tilde{s} \%$ & 3.28 & -2.30 & 0.98 \\
$\Delta \tilde{c} \%$ & -4.65 & 1.94 & -2.33 \\
$\Delta \tilde{w} \%$ & -4.44 & 0 & -4.44 \\
$U E(0)$ & 8.92 & 11.02 & 11.71 \\
$\widetilde{U E}$ & 8.41 & 8.17 & 8.40 \\
$\Delta W(0) \%$ & -4.39 & -8.29 & -12.30 \\
$\Delta \tilde{W} \%$ & -4.52 & 1.28 & -3.33 \\
\hline
\end{tabular}

Note: A tilde denotes steady state.

Evidently, the pure TFP shock of $A$ from 1.0 to 0.97 presented in the second column of Table 3

${ }^{17}$ Subsequent changes in welfare are obtained by expressing the change in the welfare measure $(2) W=\frac{1}{\epsilon} \int_{0}^{\infty}[c(t)(1-$ $\left.l(t)-s(t))^{\theta}\right]^{\epsilon} e^{-\beta t} d t$ in terms of the equivalent variations in the flow of consumption necessary to equate the initial levels of welfare to what they would be following the shocks (both in the short run and the long run; see, e. g., Schubert and Turnovsky (2011)). A more detailed description of the computation is delegated to the Appendix. 
results in a lower steady-state capital stock, output, and consumption, but permanently higher unemployment $(+3.3 \%)$, whereas the unemployment rate $\widetilde{U E}$ only slightly increases from $8.17 \%$ to $8.41 \%$. Since in steady-state the interest rate has to be equal to the time preference rate, the risk premium has to remain unchanged. As output falls, the economy's foreign debt has to fall. The lower capital stock reduces the marginal product of labor, and the consumption cut lowers agents' reservation wages. Thus, the bargained steady-state wage falls by $4.4 \%$. Note that labor approximately remains constant.

If the economy is hit by a pure interest rate shock, that is by an increase in the risk premium, the steady-state effects are quite different. Whereas the capital stock and output again fall, albeit by a somewhat smaller amount, the economy's debt dramatically reduces by two thirds. The reason is again that the steady-state risk premium has to remain constant, requiring thus a large debt reduction. In turn, despite the fact that output falls, the reduction in steady-state debt frees resources which allows higher consumption $(+2 \%)$. In the wage bargain, lower marginal productivity of labor (because the capital stock is lower) is offset by a higher reservation wage (because of higher consumption), and the steady-state wage approximately remains constant. Because higher consumption can be financed with resources not longer used for debt service, the need to work and to search for a job is dampened. Employment $l$ and unemployment $s$ both fall by $2.3 \%$, and the steady-state unemployment rate remains constant. Lower labor and search and higher consumption are welfare increasing, implying that the reduced willingness to lend to the economy is welfare-improving in the long run (on this somewhat paradoxical result, see Eicher, Schubert, and Turnovsky (2008)).

If both shocks hit the economy at once, the final column in Table 3 reveals that the long-run reductions in capital and output are magnified, whereas the increase in unemployment and the consumption drop are dampened, compared to the case of a pure TFP shock. The reason for this is simple. The long-run debt reduction frees resources, and this dampens the negative effect of the TFP shock.

\section{Dynamic Effects of a Permanent Technology Shock}

In Fig. 1, we graph the transition following a permanent technology shock from $A=1.0$ to $A=0.97$ (and constant $\eta$ ). With the exception of the interest rate and national foreign debt, all variables are plotted relative to their respective initial base levels.

On impact, the $3 \%$ TFP drop reduces output by $3 \%$ and lowers the marginal productivity of capital and thus its market price, $q$, causing a reduction in investment and starting a decumulation of the capital stock. The shock's negative wealth effect induces agents to cut back consumption and to 
Figure 1: Transition after a permanent technology shock
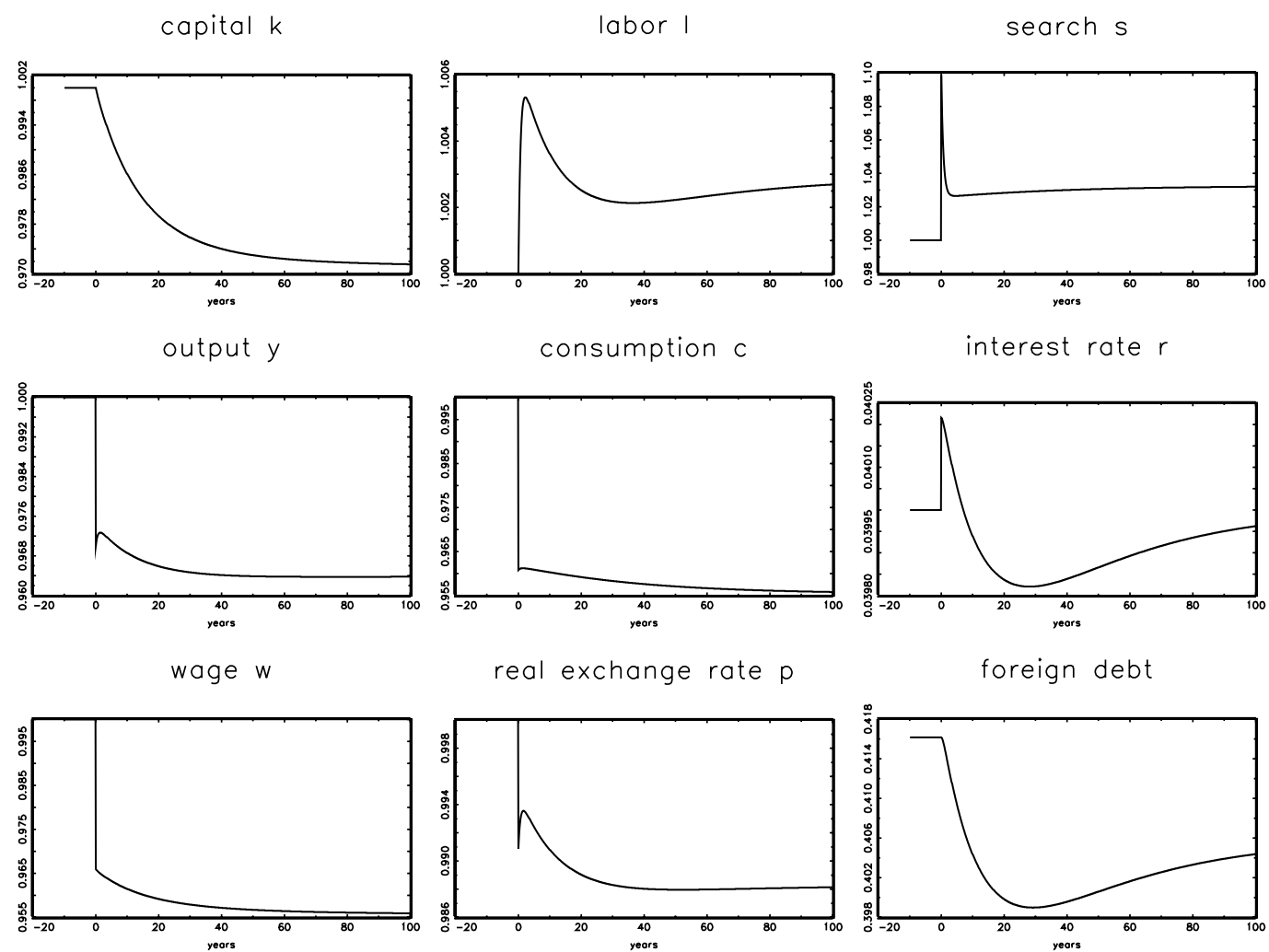

increase search, resulting in a $10 \%$ increase in unemployment, $s$. The unemployment rate $U E(0)$ jumps up to $8.92 \%$, as presented in Table 3. Higher search (unemployment) and lower consumption lead to an instantaneous welfare loss $\Delta W(0)$ of $4.39 \%$. We have two opposing effects on the risk premium, $\omega(p n / y)$. On the one hand, output $y$ drops. On the other hand, the real exchange rate appreciates (a fall of $p$ ). As the decline in output is higher than the reduction in domestic aggregate demand, the real exchange rate has to appreciate by roughly $1 \%$ to maintain goods market equilibrium. The net effect on $p n / y$ is positive so that the risk premium increases, pushing up the interest rate by roughly 2.5 basis points. Facing the increased debt service together with lower output, leaving less resources for investment and consumption, the economy starts to reduce its debt. This is achieved by a current account surplus, as the reduction in consumption of the foreign good, $c_{f}$, outweighs the reduction in the export value in terms of the foreign good, $Z / p$. Hence, in the first part of the transition, the economy lowers its debt, which in turn reduces the risk premium. The pre-shock interest rate $(4 \%)$ is quickly approached after roughly seven years, and the interest rate remains lower thereafter. The reduced debt and the lower interest rate reduce the debt service, allowing thus to mitigate consumption cuts, compared to the case of a fixed interest rate. 
As debt service becomes lower and lower over time, agents can afford a relatively high level of imports, whereas domestic goods market clearance calls for an ongoing appreciation (a fall in $p$ ) because of successively lower production. The appreciation in turn reduces the export value and raises imports $c_{f}$, ceteris paribus, worsening thus the trade balance. Hence, the current account deteriorates over time, and debt decumulation slows down and eventually stops. The interest rate has reached its minimal level during transition. From thereon, the financing of domestic expenditures requires new borrowing, and the debt position starts worsening as the stock of debt accumulates. In turn, this raises the risk premium, and the interest rate starts to increase. The country faces a capital flow reversal. ${ }^{18}$ However, compared to the pre-shock situation, the economy ends up with a lower stock of debt.

After its impact increase by $10 \%$, unemployment, $s$, returns quickly to a level roughly $3 \%$ higher than before the shock occurred, because agents become discouraged and reduce search efforts, and starts rising marginally from thereon, as agents still try to get jobs in an attempt to lower the burden of the debt service. The evolution of employment mirrors that of search, as an increase in search makes it easier for firms to match job vacancies with searching agents. However, the changes in employment (labor $l$ ) are quantitatively small.

In steady state, the country ends up with a slightly reduced stock of debt, lower capital, output ($3.6 \%)$ and consumption, and higher unemployment as well as with an increased unemployment rate (8.41\%). As one can see from Fig. 1, most of the output, consumption, wage, and real exchange rate adjustment happens on impact. The changes in the interest rate and debt are small and reflect the fact that a pure TFP shock mainly affects the economy's supply side with little effect on the balance of payments. The intuition behind that is straightforward. As the supply side of the economy is affected, a change in the relative price $p$ maintains goods market equilibrium. The induced changes in consumption, exports, and other key economic variables affect the current account and the interest rate premium only in an indirect and modest way. Hence, the pure TFP shock has an almost negligible effect on the interest rate risk premium and the economy's debt position. The overall welfare loss is considerable and amounts to $4.52 \%$.

We can summarize that the effects of this pure supply side shock are considerable with respect to capital, output, consumption, and employment, but very small with respect to the interest rate and debt.

\footnotetext{
${ }^{18}$ On the issue of a capital flow reversal, see Eicher, Turnovsky, and Walz (2000), who study the effects of a financial market liberalization.
} 


\section{Dynamic Effects of a Permanent Shock on $\eta$}

We now turn to a pure shock in the risk premium, holding TFP constant. The financial crisis led to a remarkable reduction in financial markets' willingness to lend, in particular to already highly indebted countries like Greece, Ireland, and Portugal. We assume that the risk premium parameter $\eta$ rises permanently from 0.01 to 0.03 . This leads to an immediate increase in the domestic interest rate. In Fig. 2, we graph the transition following this shock.

Figure 2: Transition after a permanent shock on $\eta$
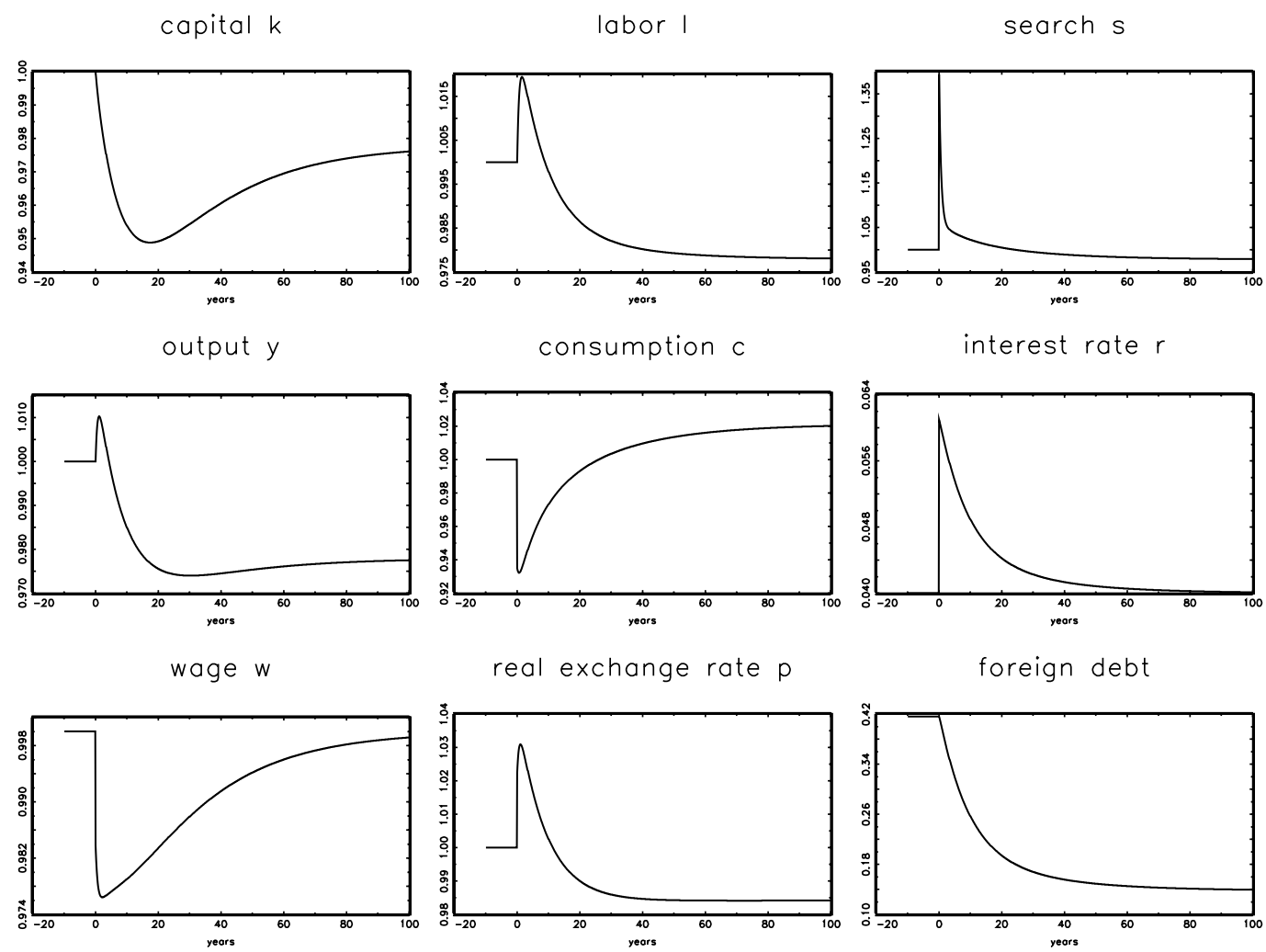

As the shock is a pure financial one, on impact production remains unaffected. However, the shock's wealth effect induces agents to cut back consumption, and the higher domestic interest rate chokes investment; thus, the real exchange rate has to depreciate ( $p$ has to increase) by roughly $3 \%$ to maintain goods market clearance. The increase in $p$ raises the debt-GDP ratio, $p n / y$, despite the fact that output does not change on impact, and induces a further increase in the domestic interest rate above its increase due to the higher $\eta$. On impact, the interest rate $r$ increases from $4.0 \%$ to $6.2 \%$.

The increase in the interest rate leads to a dramatic increase in debt service, requiring additional resources to be financed. Hence, in sum on impact agents have to cut back consumption by roughly 
7\%. In an attempt to maintain consumption, they increase their search efforts, resulting in a tremendous increase in unemployment by roughly $40 \%$. This pushes the unemployment rate $U E(0)$ up to $11 \%$ (see Table 3 ). The instantaneous welfare loss is $8.29 \%$, stemming from lower consumption and higher search. Higher search in turn makes it easier for firms to match their job vacancies. In addition, the reservation wage of the households is reduced. ${ }^{19}$ Consequently, employment starts to increase. After one year or so, employment is roughly $1.5 \%$ higher than it was before the shock happened. Offsetting the effect of the falling capital stock, the sharp increase in employment raises output in the very first stage of transition. The sharp reduction in consumption and the real depreciation turns the current account into surplus, and the economy starts reducing its debt.

Higher GDP and falling foreign debt reduces the risk premium, and the interest rate falls. Declining debt and debt service allow more resources to be used for consumption. Thus, after its impact drop consumption rises. As the capital stock falls, output quickly reverses its transition and starts to fall, requiring a real appreciation ( $p$ has to fall) to maintain goods market equilibrium. The falling $p$ contributes to interest rate reductions, as $p n / y$ becomes smaller. In turn, the lower interest rate stimulates consumption and starts to raise the agents' reservation wage again, resulting in increasing bargained wages, whereas the trade balance deteriorates due to the falling real exchange rate. Hence, the decumulation of debt slows down over time.

After roughly 20 years, the interest rate is sufficiently close to its steady-state level to make investment in capital attractive and to reverse the evolution of the country's capital stock. From thereon, the gradually increasing capital stock outweighs lower employment and results in a slightly rising output, but the capital stock remains below its pre-shock level.

In the long run, the economy's stock of foreign debt is substantially lower, implying a much smaller debt service. Accordingly, agents can afford to consume more despite the fact that output is permanently lower $(-2.15 \%)$.

Unemployment quickly falls after its huge impact increase $(+40 \%)$, and since the long-run debt service is sufficiently smaller, agents have less incentive to search for jobs, resulting in a steadystate reduction of unemployment by $2.3 \%$ and an unchanged long-run unemployment rate. ${ }^{20}$ Also, the quick reduction in search efforts makes it more difficult to match job vacancies, and employment (labor $l$ ) falls after its initial increase. In fact, employment and unemployment move in tandem.

The differences to a pure TFP shock are striking. Comparing Figs. 1 and 2, it is evident that the dynamics following the risk premium shock are much more pronounced and long-lasting. The adjustment of output, consumption, wages, labor, the real exchange rate, and the interest rate takes

\footnotetext{
${ }^{19}$ It is immediately evident from (10) that a fall in both $c$ and $s$ reduces $w$.

${ }^{20}$ Labor and search drop by approximately the same percentage so that the unemployment rate is close to its old steady-state value prior to the shock.
} 
a long time; only after roughly 40 years the major part of adjustment is accomplished. The reason is that the shock directly affects the current account and the interest rate, and that debt can only adjust gradually. In contrast to a pure TFP shock, there is no capital flow reversal, but a reversal in the economy's physical capital stock.

In the long run, the sharply reduced debt allows the economy to produce less, requiring less labor and capital, and to consume more. The overall welfare effect of the risk premium shock is, somewhat paradoxically, positive $(+1.28 \%)$. Despite the fact that the impact effects of the shock (large consumption cut and large increase in job search) cause a considerable immediate welfare loss (8.29\%), consumption recovers during transition, whereas labor and search fall, thus increasing instantaneous welfare. Intertemporally, the impact welfare loss is more than compensated by future welfare increases, so that long-run welfare rises. Thus, a debtor economy is better off in having its access to the international financial market restricted. For countries like Greece, Ireland, and Portugal this means that despite the short-run effects of the shock are very unpleasant and painful, in the long run they gain.

\section{Dynamic Effects of a Combined Permanent Shock on $A$ and $\eta$}

Some countries were hit by the crisis in two ways suffering from both a TFP shock and an increase in the risk premium. In this section, we investigate the economy's transition after a combined TFP and risk premium shock. For this purpose we assume that $A$ drops from 1.00 to 0.97 and $\eta$ increases from 0.01 to 0.03 . In Fig. 3, we graph the transition following this shock.

Comparing Fig. 3 with Figs. 1 and 2, we see that the dynamic transition resembles the one in case of a risk premium shock. The intuition is simple: The TFP as a supply side shock mainly impinges on output, with little effect on the interest rate (see Section 5), whereas the interest rate shock hits the economy by (i) increasing its debt service and directly affecting the current account, and by (ii) interfering with the no-arbitrage conditions (equations (3c), (6c) and (6d)), thus changing saving, investment, and search unemployment. In case of the combined shock, the effects on capital, output, search, and the interest rate are magnified compared to the pure TFP shock. The short-run unemployment rate jumps up to $11.7 \%$. The impact effect on consumption is magnified, too, and the instantaneous welfare loss amounts to $12.3 \%$, whereas the long-run consumption reduction is dampened, because the economy's reduced debt lowers its debt service. In other words, in the long run the two shocks reinforce themselves with respect to capital and output (-5.74\%), whereas they dampen each other with respect to consumption and welfare. In particular, the dynamic adjustment is sluggish, stemming mainly from the risk premium shock. The short-run welfare loss of the combined shock is $12.3 \%$ whereas its long-run welfare loss is $3.33 \%$, where the latter number comes close to the sum of the welfare effects of the pure TFP shock $(-4.52 \%)$ and the pure risk 
Figure 3: Transition after a permanent shock on $A$ and $\eta$

capital k

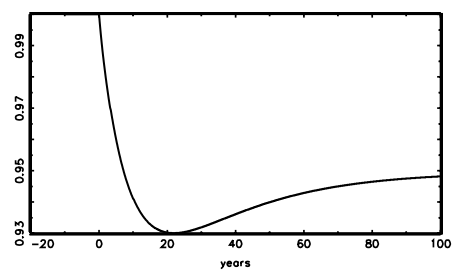

output y

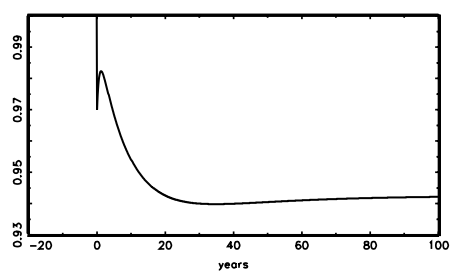

wage w

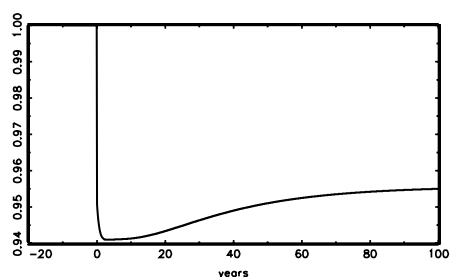

labor |

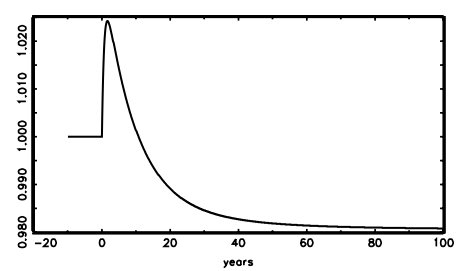

consumption $c$

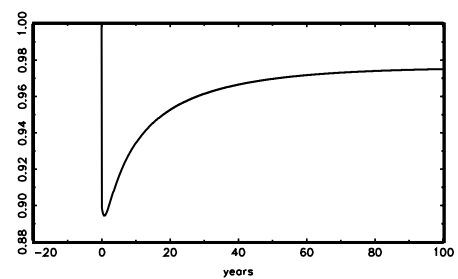

real exchange rate $p$

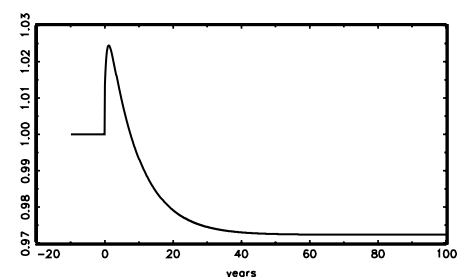

search s

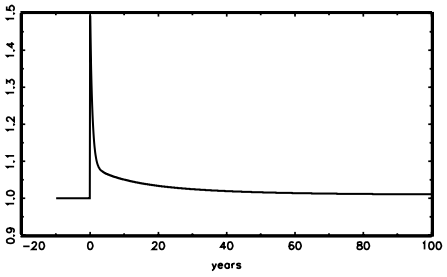

interest rate $r$

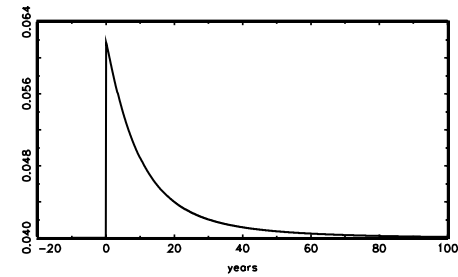

foreign debt

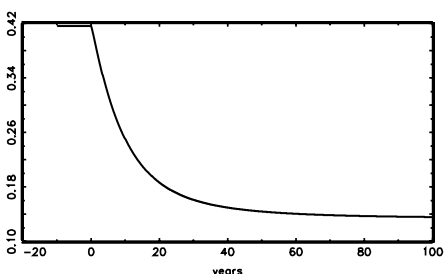

premium shock $(+1.28 \%)$. Hence, in the long run a debtor economy being hit simultaneously from both shocks suffers less than in the case of a pure TFP shock, because the long-run debt reduction is - viewed in isolation - welfare improving.

\section{Debt Cancelation}

We briefly address the current discussion of a so-called haircut, that is, a partial debt forgiveness for countries like Greece. For that purpose, we shall assume that foreigners agree to cancel $50 \%$ of the economy's foreign debt at time zero (when the combined shock occurs). In this case, the transition dynamics of the economic variables as illustrated in Fig. 4 behave a little different than in the benchmark case displayed in Fig. 3.

The main difference is that debt and thus debt service are reduced on impact. Consequently, despite the risk premium shock, the interest rate increases only by 60 basis points to $4.6 \%$. The resources set free due to lower debt service in turn allow for relatively small consumption cuts, and reduce the incentives to search for jobs. Hence, on impact unemployment (search) falls by $2.5 \%$. This lowers firms' ability to fill vacant jobs, and employment starts to fall. The instantaneous welfare loss is 
Figure 4: Transition after a permanent shock on $A$ and $\eta$ and debt cut in half
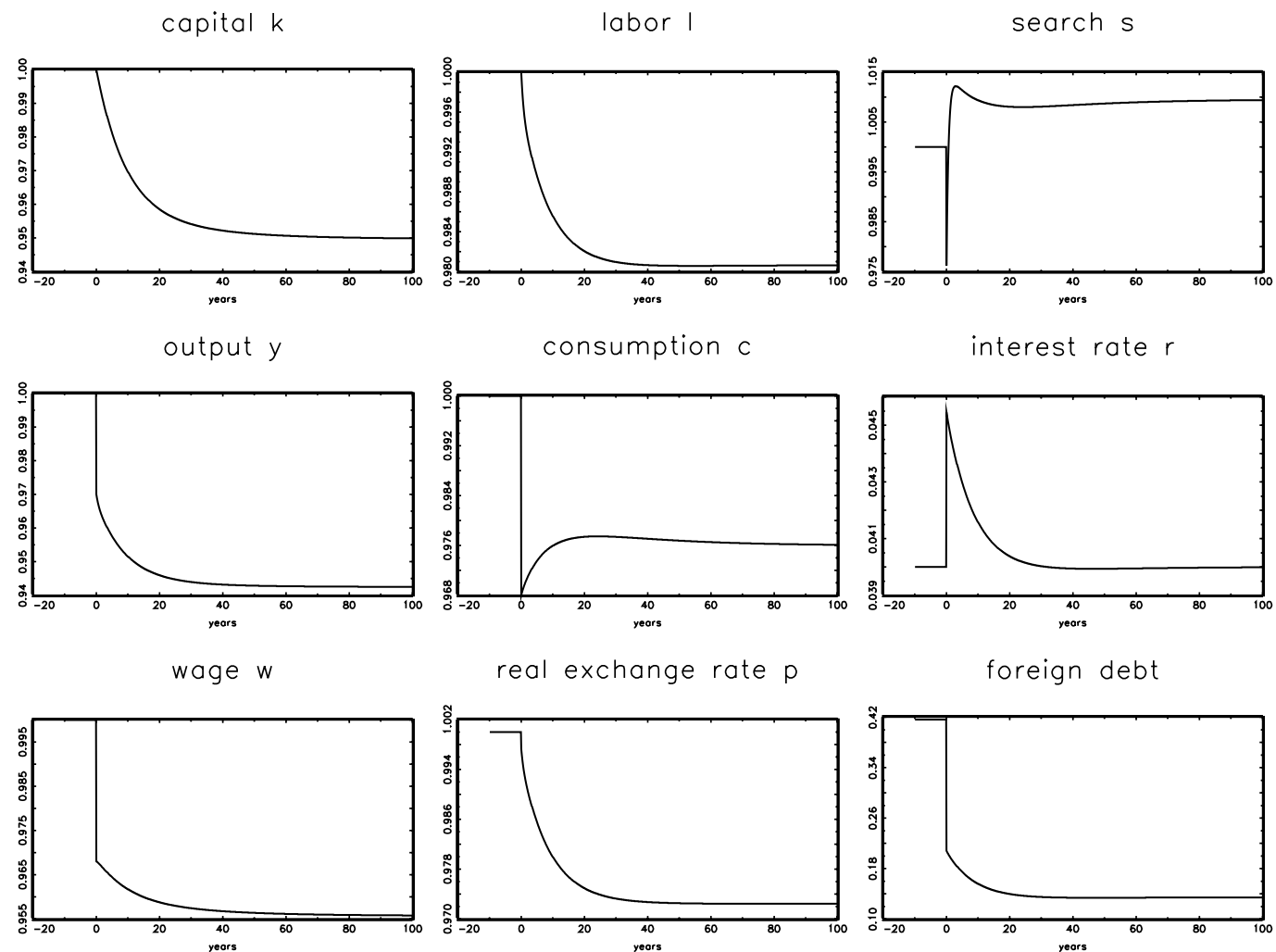

real exchange rate $p$

foreign debt
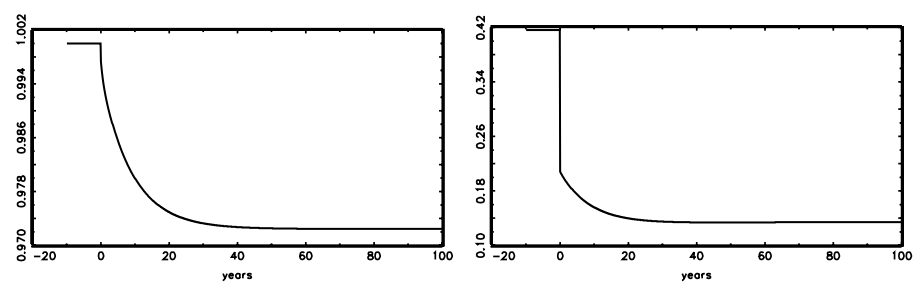

scaled down to $3.09 \%$. The decumulating capital stock and lower employment reduce production further. This in turn requires further debt reduction, as the ability to service the debt declines, brought forward by a current account surplus. However, after the haircut the evolution of debt and the interest rate is quantitatively small. As output continues to fall, agents try to get jobs to maintain their consumption level, so that job search (unemployment) increases quickly and then permanently remains on a somewhat higher level $(+1 \%)$. During transition, capital, employment (labor), output, the wage rate, the real exchange rate, and debt all fall monotonically, whereas consumption and search evolve in an non-monotonic manner.

Most importantly, the effect of a debt cancelation as a reaction upon the combined shock is huge. In fact, the welfare loss of the productivity drop and the increase in borrowing costs $\eta$ decreases from $3.33 \%$ to $1.45 \%$. 


\section{Transitory Technology Shocks and Real Wage Rigidity}

In the following, we study the effects of a temporary shock TFP shock. $A$ falls from 1.0 to 0.97 in period $t=0$ and afterwards, it follows the $\mathrm{AR}(1)$ process:

$$
\dot{A}=-\rho_{A}(A-\tilde{A})
$$

We set the autoregressive parameter $\rho_{A}$ equal to 0.05 in accordance with Ríos-Rull (1996) who chooses the $\mathrm{AR}(1)$ parameter 0.95 for a discrete-time process for annual data. The steady-state value $\tilde{A}$ equals unity, implying that $A$ returns to its long-run level.

So far, we have assumed flexible wages. As shown by Hall (2005) and Blanchard and Galí (2010) in a related model with search unemployment and matching frictions, wage stickiness helps to improve the modeling of the unemployment response to a productivity shock. For this reason, we will distinguish two cases for the wage setting in this section: (i) continuous wage bargaining, and (ii) sticky wages.

In the first case, wages are set as in (10). Hall (2005), however, argues that many wage rules are consistent with an equilibrium as long as they generate a positive surplus for both the firm and the workers. The Nash bargaining solution is just one of the possible allocation mechanism. In the second case, we follow Blanchard and Galí (2010) and assume that the wage schedule depends on productivity $A$ :

$$
w=\Theta A^{1-\gamma}
$$

with $\gamma \in[0,1]$ denoting an index of real wage rigidity and $\Theta>0$. We also follow these authors and choose the value $\gamma=0.5$. We assume that in steady state the wage is equal to the Nash bargaining solution implying ${ }^{21}$

$$
\Theta=\varrho(1-\alpha) \tilde{A}^{\gamma-1-\rho}\left(\frac{\tilde{y}}{\tilde{l}}\right)^{1+\rho}+(1-\varrho) \frac{\theta \tilde{P} \tilde{c} \tilde{A}^{\gamma-1}}{(1-\tilde{l}-\tilde{s})\left(1-\tau_{w}\right)}
$$

In Fig. 5, we graph the dynamics following a transitory technology shock from $A=1.0$ to $A=0.97$; in addition, $\eta$ increases permanently to 0.03 . Evidently, as a consequence of rigid wages, productivity shocks generate a much more persistent response of unemployment. While the search effort of the households returns to the old steady state level basically within the first three years in the case of flexible wages (solid line), it remains well above the steady-state level in case of sticky wages. Notice also that the responses of output, capital, and the interest rate are more pronounced in the case of sticky wages as well because wages do not fall sufficiently in response to a productivity shock due

\footnotetext{
${ }^{21}$ It is easy to show that our wage rule implies a positive surplus for both the firm and the household in steady state and during the transition.
} 
Figure 5: Transition with a transitory technology shock and a risk premium shock

productivity $A$

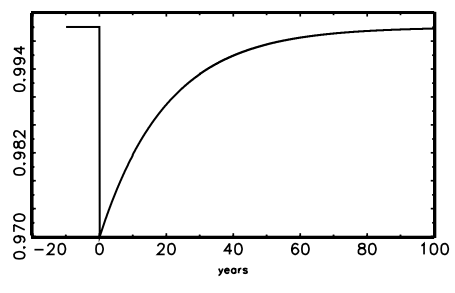

search s

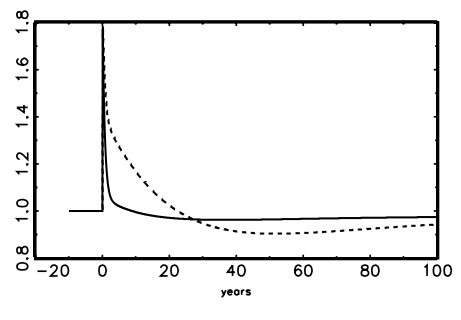

wage w

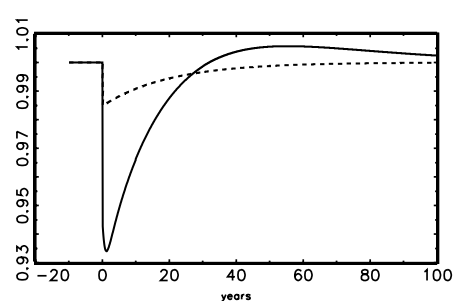

capital k

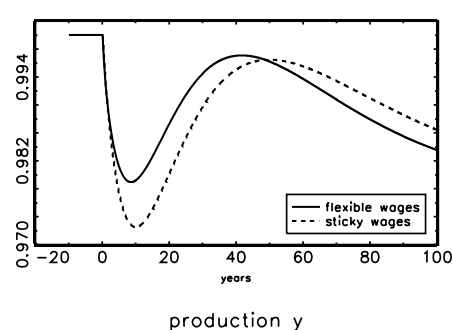

production $y$

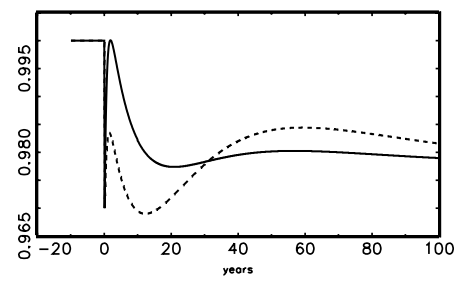

real exchange rate $p$

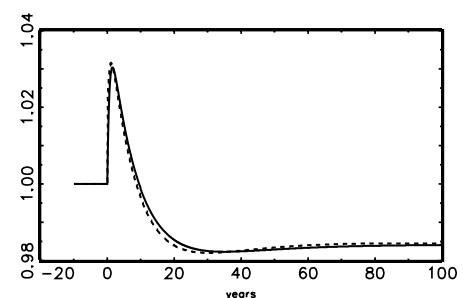

labor I

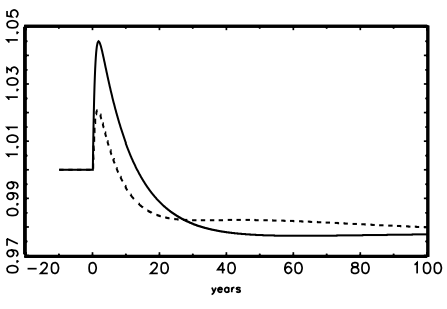

interest rate $r$

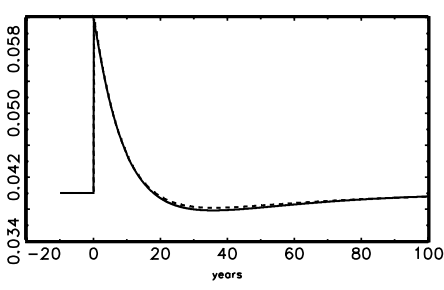

foreign debt

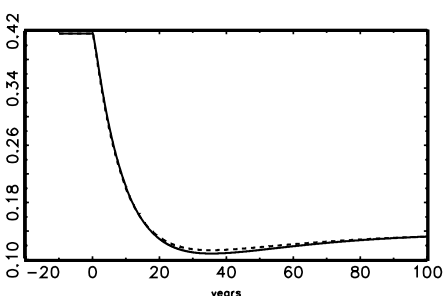

to the rigidity. In turn, higher sticky wages provide more incentives for households to search for jobs. Thus, search unemployment is much more persistent compared to the flexible wage case. On the other hand, firms post fewer vacancies because of the higher wage. Hence, despite more search efforts, less jobs are matched, and labor reacts much more moderately than in case of flexible wages. Less labor flexibility in turn is also reflected in a lower output during the first 30 years after the shock. In the long run, the stronger decline in capital creates a more pronounced swing in output. ${ }^{22}$ In contrast, there are barely any differences with respect to the real exchange rate, the interest rate, and the stock of foreign debt. Again, sticky wages impinge on the economy's supply side and have little effects on its external sector.

An interesting finding is that welfare is higher in case of sticky wages compared to the case with flexible wages. At a first glance, this seems to be counterintuitive. However, the wage bargain itself is associated with a welfare loss. ${ }^{23}$ Sticky wages may thus counterbalance this loss to some extent.

\footnotetext{
${ }^{22}$ Note that during the first 40 years capital falls by more than in case of flexible wages because the marginal product of capital is relatively lower, due to a relatively higher capital-labor ratio, compared to the flexible wage case.

${ }^{23}$ The wage bargain is only efficient if the Hosios (1990) condition holds, which in general and in particular in the presence of taxes will not be the case.
} 
Since the TFP shock mitigates as time goes by and vanishes in the long run, only the risk premium shock remains permanently. The economy ends up with much lower debt, allowing therefore less production and labor and more consumption. Thus, from an intertemporal perspective, welfare increases. In the case of sticky wages, the welfare gain is $2.05 \%$, compared to $1.63 \%$ in the case of flexible wages.

\section{Conclusion}

In this paper we have analyzed the impacts of TFP and risk premium shocks on the economic performance of a highly indebted open economy. The analysis is based on the well-known semi-small open economy model of the Turnovsky (2000, ch. 11) type, where an upward sloping supply curve of debt is added. The key feature of the economy is that the labor market is non-Walrasian and suffers from frictions. Unemployment emerges as matching of job vacancies with searching agents is timeconsuming and costly. Because of the model's complex dynamic structure, we resorted to numerical simulations, enabling us to analyze the short-run dynamics and the steady-state adjustments. We also have introduced sticky wages à la Blanchard and Galí (2010). We calibrated the model to replicate some structural key characteristics of highly indebted advanced economies like Greece, Ireland, or Portugal, which in the aftermath of the global financial crisis run into severe troubles both in terms of economic performance and in terms of their ability to borrow on the international financial market.

We find that a pure total factor productivity (TFP) shock has mainly supply side effects and barely affects the economy's foreign debt and the interest rate risk premium. Much of the adjustment to the shock occurs on impact, and the welfare loss of a permanent $3 \%$ decline in TFP is considerable (4.5\%). In contrast, a pure risk premium shock causes considerable dynamic adjustments, during which the economy substantially reduces its debt. On impact, the shock causes unemployment to increase sharply, raising the unemployment rate from $8.17 \%$ to $11 \%$ and leading to a large instantaneous welfare loss $(8.3 \%)$. However, the shock is associated with an intertemporal welfare gain $(+1.28 \%)$, as lower debt service allows higher consumption and leisure and less production.

If both shocks jointly hit the economy, the dynamics closely follow that in case of a pure risk premium shock. The short-run unemployment rate is pushed up to $11.71 \%$, and the instantaneous welfare loss is huge (12.3\%), whereas the intertemporal welfare loss (3.33\%) is considerably dampened. If we compare these results to the empirical observations on Portugal, Ireland, Greece, and Spain mentioned in the Introduction, we recognize that the two shocks are potentially able to explain a

large part of the behavior of the unemployment rates in these countries. While in our model the unemployment rate increases by $34 \%$, it increased by 37\%-198\% in these countries during 2007-2010. Of course, we acknowledge that other factors in these countries contributed to the high increases 
in the unemployment rates that we do not model here, for example the sectoral shocks in the real estate sector in Spain and the financial sector in Ireland.

If the productivity shock is only temporary, the positive effects of the risk premium shock prevail in the long run, and welfare increases by $1.63 \%$. If wages are sticky, the welfare gain is even larger $(2.05 \%)$.

We can thus conclude that to the extent that highly indebted countries like Greece and others are mainly hit by an interest rate shock, despite the fact that the short-run effects of that shock are painful, they will eventually be able to gain in the long run.

\section{Acknowledgements}

An earlier version of this paper was presented at the workshop "Advances in Dynamic Macroeconomics", May 23 - 27, 2011, Free University of Bozen-Bolzano, School of Economics and Management. We wish to thank an anonymous referee and the workshop participants for useful comments and suggestions. Of course, all remaining errors are ours. 


\section{References}

Auerbach, A., and L. Kotlikoff (1987): Dynamic Fiscal Policy. Cambridge University Press, New York.

Backus, D. K., P. J. Kehoe, and F. E. Kydland (1994): "Dynamics of the Trade Balance and the Terms of Trade: The J-Curve?," The American Economic Review, 84(1), 84 - 103.

Barro, R. J., And X. SAla-I-Martin (2003): Economic Growth. MIT Press, Cambridge Mass., 2nd edn.

Bayoumi, T. (1999): "Estimating Trade Equations from Aggregate Bilateral Data," IMF Working Paper WP/99/74.

Blanchard, O., and J. Galí (2010): "Labor Markets and Monetary Policy: A New Keynesian Model with Unemployment," American Economic Journal: Macroecononomics, 2(2), 1 - 30.

Carey, D., and H. Tchilinguirian (2000): "Average Effective Tax Rates on Capital, Labour and Consumption," OECD Economics Department Working Papers, No. 258, OECD Publishing, doi:10.1787/247874530426.

Chatterjee, S., and S. J. Turnovsky (2007): "Foreign Aid and Economic Growth: The Role of Flexible Labor Supply," Journal of Development Economics, 84, 507 - 533.

Chung, K., and S. J. Turnovsky (2010): "Foreign Debt Supply in an Imperfect International Capital Market: Theory and Evidence," Journal of International Money and Finance, 29(2), 201 $-223$.

Colacelli, M. (2008): "Export Responses to Real Exchange Rate Fluctuations: Development Status and Exported Good Effects," Working Paper, Columbia University.

Cole, H. L., L. E. Ohanian, and R. Leung (2005): "Deflation and the International Great Depression: A Productivity Puzzle," NBER Working Paper 1123\%.

EDwards, S. (1984): "LDC Foreign Borrowing and Default Risk: An Empirical Investigation 1976-80," American Economic Review, 74, 726- 734.

Eicher, T. S., S. F. Schubert, and S. J. Turnovsky (2008): "Dynamic Effects of Terms of Trade Shocks: The Impact on Debt and Growth," Journal of International Money and Finance, $27,876-896$. 
Eicher, T. S., S. J. Turnovsky, and U. Walz (2000): "Optimal Policy for Financial Market Liberalizations: Decentralization and Capital Flow Reversals," German Economic Review, 1, $19-42$.

Elschner, C., and W. Vanborren (2009): "Corporate Effective Tax Rates in an Enlarged European Union," Taxation Papers.

Estevão, M., And T. Severo (2010): "Financial Shocks and TFP Growth," IMF Working Paper $W P / 10 / 23$.

Hall, R. E. (2005): "Employment Fluctuations with Equilibrium Wage Stickiness," The American Economic Review, 95(1), 50 - 65.

Haugh, D., P. Ollivaud, and D. Turner (2009): "The Macroeconomic Consequences of Banking Crises in OECD Countries," OECD Economics Department Working Papers, No. 683, OECD Publishing, doi:10.1787/226123651438.

Heer, B. (2003): "Welfare Costs of Inflation in a Dynamic Economy with Search Unemployment," Journal of Economic Dynamics and Control, 28, 255 - 272.

Hobijn, B., And A. ŞAHIn (2009): "Job-Finding and Separation Rates in the OECD," Economics Letters, 104, 107 - 111.

Hooper, P., K. Johnson, and J. Marquez (2000): "Trade Elasticities for the G-7 Countries," Princton Studies in International Economics, No. $8 \%$.

Hosios, A. J. (1990): "On the Efficiency of Matching and Related Models of Search and Unemployment," Review of Economic Studies, 57, 279 - 298.

IMF (2009): World Economic Outlook, October 2009, Sustaining the Recovery. International Monetary Fund, Washington, D.C.

Lim, G. C., And P. D. McNelis (2008): Computational Macroeconomics for the Open Economy. MIT Press, Cambridge, Massachusetts.

Meza, F., And E. Quintin (2005): "Financial Crises and Total Factor Productivity," Federal Reserve Bank of Dallas Working Paper 0105.

Min, H. G. (1998): "Determinants of Emerging Markets Bond Spread: Do Economic Fundamentals Matter?," World Bank Policy Research Working Paper No. 1899. 
Mortensen, D. T., And C. A. Pissarides (1994): "Job Creation and Job Destruction in the Theory of Unemployment," The Review of Economic Studies, 61(3), 397 - 415.

Obstfeld, M., And K. Rogoff (1996): Foundations of International Macroeconomics. MIT press, Cambridge, Massachusetts.

Ortigueira, S., And M. S. Santos (1997): "On the Speed of Convergence in Endogenous Growth Models," American Economic Review, 87, 383 - 399.

Papageorgiou, C. (2008): "Comment on "Unwrapping some Euro Area Growth Puzzles: Factor Substitution, Productivity and Unemployment"," Journal of Macroeconomics, 30, 667 - 670.

Petrosky-Nadeau (2010): "TFP during a Credit Crunch: The Macroeconomics of Credit and Job Destruction," GSIA Working Papers 2010-E70.

Pissarides, C. A. (1986): "Unemployment and Vacancies in Britain," Economic Policy, 1, 499 559.

(1987): "Search, Wage Bargains and Cycles," The Review of Economic Studies, 54, 473 483.

(2000): Equilibrium Unemployment Theory. MIT press, Cambridge, Massachusetts, 2nd edn.

Ríos-Rull, J.-V. (1996): "Life-Cycle Economies and Aggregate Fluctuations," Review of Economic Studies, 63(3), $465-489$.

Rogerson, R., And R. Shimer (2010): "Search in Macroeconomic Models of the Labor Market," NBER Working Paper Series, Working Paper 15901.

Schubert, S. F. (2011): "The Effects of Total Factor Productivity and Export Shocks on a Small Open Economy with Unemployment," Journal of Economic Dynamics and Control, 35, 1514 1530.

Schubert, S. F., and S. J. Turnovsky (2011): "The Impact of Oil Prices on an Oil-Importing Developing Economy," Journal of Development Economics, 94, 18 - 29.

SHI, S. (2001): "Tariffs, Unemployment, and the Current Account: an Intertemporal Equilibrium Model," in Money, Factor Mobility and Trade: Essays in Honor of Robert A. Mundell, ed. by 
G. A. Calvo, R. Dornbusch, and M. Obstfeld, chap. 14, pp. 467 - 504. MIT Press, Cambridge, MA.

Shi, S., And Q. Wen (1997): "Labor Market Search and Capital Accumulation: Some Analytical Results," Journal of Economic Dynamics and Control, 21, 1747 - 1776.

(1999): "Labor Market Search and the Dynamic Effects of Taxes and Subsidies," Journal of Monetary Economics, 43, 457 - 495.

Turnovsky, S. J. (2000): Methods of Macroeconomic Dynamics. MIT Press, Cambridge, Massachusetts, second edn.

Zoli, E. (2004): "Credit Rationing in Emerging Economies' Access to Global Capital Markets," IMF Working Paper No. WP/04/70. 